\title{
Innovation and the Development Convention in Brazil*
}

\section{Fabio Stefano Erber}

Instituto de Economia, Universidade Federal do Rio de Janeiro

\section{ABSTRACT}

From the beginning of the nineties the Brazilian economy was ruled by a specific view of the process of economic development, which emphasized the role of technical progress as a means to achieving fast and stable economic growth. Nonetheless, the degree of endogenous technical innovation in Brazil remains very low. This paper explores the conjecture that the latter result is a consequence of the hegemonic view of development.

The first section presents some quantitative and qualitative data to support our assertion about the innovativeness of the Brazilian economy. The second section argues that the "view of development" may be profitably treated as a "convention", a set of beliefs shared by decision-makers and used to identify the main issues which a development strategy has to tackle and the appropriate means to address such issues. A development convention contains also a "negative" agenda - issues and solutions which should be avoided. The same section then analyses the development convention which was hegemonic from the nineties to the date of the paper (2002) and the implications of its positive and negative

Paper written for the workshop "Tendências e Fronteiras do Desenvolvimento: Inovação e Políticas Tecnológicas", IE/UFRJ, Centre for Research on Innovation and Competition - The Universty of Manchester, FINEP and British Council (RJ). Rio de Janeiro, September 2002. 
agendas for technological development, assuming such convention had worked as its supporters supposed it would. It argues that the theoretical results are consistent with the facts described in the first section. The last section comments the actual working of the development convention, arguing that it stressed the main technological features present in the "pure form" of the convention and concludes with a brief discussion of the role of innovation in a new development convention which seemed to be arising at that time.

KeYwORdS | Economic Development; Innovation; Convention; Development Strategy

JEL-CODES $\mid$ O10, L20, O30

\section{RESUMO}

Durante os anos noventa a economia brasileira foi governada por uma visão específica do processo de desenvolvimento econômico que enfatizava o papel do progresso técnico como um meio para atingir crescimento econômico rápido e estável. Não obstante, o grau de inovação tecnológica endógena no Brasil permanece muito baixo. Este artigo explora a conjectura de que este último resultado é uma conseqüência da visão hegemônica de desenvolvimento.

A primeira seção do artigo apresenta dados quantitativos e qualitativos para apoiar nossa afirmativa a respeito da inovação da economia brasileira. A segunda seção argumenta que a "visão de desenvolvimento" pode ser tratada como uma "convenção", um conjunto de crenças compartilhado pelos tomadores de decisão, utilizado para identificar os principais problemas que uma estratégia de desenvolvimento deve enfrentar e os meios adequados para resolver estes problemas. Uma convenção de desenvolvimento contém também uma agenda "negativa” - questôes e soluções que devem ser evitados. A mesma seção analisa a convenção de desenvolvimento que foi hegemônica dos anos noventa até a data do artigo (2002) e as implicações de suas agendas — positiva e negativa — para o desenvolvimento tecnológico, supondo que a convenção tivesse funcionado como seus defensores acreditavam. Os resultados hipotéticos são consistentes com os fatos relatados na seção inicial. A última seção comenta o efetivo funcionamento 
da convenção de desenvolvimento, argumentando que a prática exacerbou as características tecnológicas presentes na "forma pura" da convenção. Na conclusão, discute-se brevemente o papel da inovação numa nova convenção de desenvolvimento que delineava-se à época.

PalaVRAS-CHAVE | Desenvolvimento Econômico; Inovação; Convenção; Estratégia de Desenvolvimento

Códigos JEL | O10, L20, O30

\section{Introduction}

From the beginning of the nineties to the present the Brazilian economy was ruled by a specific view of the process of economic development, which emphasized the role of technical progress as a means to achieving fast and stable economic growth. Nonetheless, the degree of endogenous technical innovation in Brazil remains very low. This paper explores the conjecture that the latter result is a consequence of the hegemonic view of development.

The next section presents some quantitative and qualitative data to support our assertion about the innovativeness of the Brazilian economy. The third section argues that the "view of development" may be profitably treated as a "convention", a set of beliefs shared by decision-makers and used to identify the main issues which a development strategy has to tackle and the appropriate means to address such issues. As discussed in more detail below, a development convention contains also a "negative" agenda — issues and solutions which should be avoided. The same section then analyses the development convention which was hegemonic from the nineties to date and the implications of its positive and negative agendas for technological development, assuming such convention had worked as its supporters supposed it would, it argues that the theoretical results are consistent with the facts described in the previous section. The last section comments the actual working of the development convention, 
arguing that it stressed the main technological features present in the "pure form" of the convention and concludes with a brief discussion of the role of innovation in a new development convention which seems to be arising.

\section{The innovativeness of the Brazilian economy}

Economists of every persuasion share now a consensus: technical innovation is one of the main drivers of development. The Brazilian economy is one of the largest in the world and faces enormous social and economic problems which place a large premium on growth and development. Therefore, technical innovation should be a strong priority in the country's development strategy.

It is arguable that Brazil has some good conditions to attain a high level of innovativeness. For instance, its education system churns out a fairly high number of PhDs in science and engineering - higher, in fact, than those which graduate in South Korea, a country which can be used for the purposes of benchmarking in terms of technical innovation. The quality of such manpower is borne out by the number of indexed science and technology publications again, comparable to the South Korean level, as shown in the first two lines of Table 1 .

Maintaining and expanding the system of graduate education takes up a hefty share of Brazilian R\&D expenditures (over 40\%). ${ }^{1}$ Government funds also most scientific and technical research. Business accounts for only $36 \%$ of total R\&D expenditures ${ }^{2}(0.33 \%$ of GDP), a share which is roughly half of the OECD average. The contrast with South Korea is strong, especially as regards business expenditures: in Korea, BERD's share of GDP is five times greater than in Brazil. Since in the two countries Government invests a similar share of GDP in R\&D ( $0.57 \%$ in Brazil and $0.7 \%$ in South Korea), business expenditures account for the great difference in the intensity of R\&D expenditures between the two countries: $0.9 \%$ in Brazil and 2.5\% in South Korea (see Table 1). The same difference is

\footnotetext{
The Green Book of Science and Technology, published by the Ministry of Science and Technology (MCT, 2001) estimates that $36 \%$ of total R\&D expenditures are used to pay for the wages of graduate educators. Scholarships are included in the Treasury funds. Unless otherwise stated the figures used in this Section come from the above-mentioned source.

2 The estimates of BERD in Brazil are very unreliable. On the one hand, the universe used by MCT for its estimates is limited, on the other hand, interviews indicate that enterprises tend to have poor accounts of this type of expenditure and tend to inflate their amount. It is hoped that a comprehensive study under way by IBGE (the National Statistics Institute) will provide better estimates.
} 
observed in terms of results: as shown in Table 1, during the period 1998/2000 the USPO registered an average of 3,500 South Korean patents per year, in contrast with a yearly average of 100 Brazilian patents.

TABLE 1

Innovation in Brazil and South Korea at the End of The Nineties

$\begin{array}{lcc}\text { Indicator } & \text { BRAZIL } & \text { SOUTH KOREA } \\ \text { PhD Degrees in science and engineering (1) } & 2.691 & 2.189 \\ \text { Technical and scientific indexed publications (2) } & 9.511 & 12.218 \\ \text { R\&D as a \% of GNP (3) } & 0.9 & 2.5 \\ \text { Government-funded R\&D as \% of GNP (3) } & 0.57 & 0.7 \\ \text { Business R\&D as \% of GNP (3) } & 0.33 & 1.8 \\ \text { Patents at the USPTO (4) } & 100 & 3.504\end{array}$

Notes: (1) 1997; (2) 2000; (3) Brazil: 1999; South Korea: 1998;

(4) Average 1998/2000

Source: MCT (2001).

Qualitative information about R\&D and other technological activities confirm this pattern of limited innovation. Patenting in Brazil is dominated by foreign holders, mostly affiliates of transnational firms (about $80 \%$ of patents). In their study of innovation in the State of São Paulo, Quadros et al. (1999) concluded that firms which are totally or partially foreign-controlled show a stronger propensity to introduce new products and processes as well as to employ more scientists and engineers for R\&D activities than locally-owned firms. Similarly, SOBEET (2000) argues that foreign firms have a greater R\&D intensity than local firms.

But, which type of $\mathrm{R} \& \mathrm{D}$ is conducted by these leading-edge innovators? Quadros et al. (1999) explain that "technologically new products and processes are originated in the industrialized countries, where transnational companies locate their major R\&D centers. They transfer such innovations to the South American market by adapting new products and processes to the local market needs 
or to the technical constraints to the supply of materials and components" (p.7). SOBEET (2000), a study of TNC's technological activities, confirms that "research on new products or processes are performed almost totally in the headquarters laboratories... Support activities and quality control are the [technological] activities most often performed in Brazil' (p.15). [my translation] Major adaptations are performed only when local idiosyncrasies come into play, such as the need to strengthen the suspension of cars because of the poor state of Brazilian roads.

Among locally-owned firms State enterprises used to rank highest in terms of R\&D intensity (Erber \& Amaral, 1995). The privatization process of the nineties led to substantial reductions of R\&D in some sectors (petrochemicals, telecoms, electric power) although in other sectors (steel and airplanes) competition maintained the former trajectory of investment in R\&D. Petrobras, the State energy company, is probably the enterprise with the highest R\&D budget of the country, geared to its deep-water oil exploitation.

The limited $R \& D$ investment of enterprises located in Brazil finds its counterpart in technology imports, used for the introduction of new products and processes. Such imports, as it is well known, lead to added production capabilities but do not increase the capability to innovate. This process of uneven transfer of capabilities, well studied since the seventies, ${ }^{3}$ is borne out by the more recent evidence. As shown by the evolution of labor productivity (Carvalho, 2000) and by the qualitative analysis of Castro and Proença (2001), the Brazilian industry went through a process of modernization of production processes but, according to the latter authors, still sorely lags behind in innovation capability.

\section{The development convention ${ }^{4}$}

Conventions are sets of beliefs shared by a community for, among other purposes, problem-setting and problem-solving. They are a heuristic device for dealing with uncertainty. Conventions may stem from different sources:

3 For a survey of the Brazilian literature of the period see Erber (1981) and references therein.

4 I owe to Castro (1993) the idea of a "development convention". His analysis of the "growth" and "stability" conventions ruling Brazilian development until the late eighties is a masterpiece. Schön (1993) helped to develop the idea further. The notion of "positive" and "negative" agendas comes from Lakatos' (1970) "research programs". 
religion, myths, scientific theories, etc. Since the Enlightenment the prestige of science as a source of conventions has increased, albeit at the cost of dressing up other sources (such as myths) in the guise of scientific theories.

In order to perform their roles in terms of problem-setting and problemsolving, conventions must be discriminating: "anything goes" is not a helpful convention. Therefore, conventions embody a set of criteria which specify a "positive agenda", the set of problems which should be tackled and a set of solutions which should be used to solve such problems. The criteria also specify a "negative agenda", problems which are not relevant and solutions to (relevant) problems which should be avoided. The importance of clearcut criteria increases in the measure of the complexity of the set of problems to be solved.

The strength of conventions depends on the adhesion of decision-makers and we may speak of hegemonic conventions in specific societies during some periods of time, as in the cases of absolute monarchy in XVIII ${ }^{\text {th }}$ Century France and of neo-liberalism during the nineties in Latin America. Nonetheless, complex problems may evoke different conventions to solve them, as shown by the persistence of upholders of monarchy. Moreover, disagreement about important criteria which structure the convention (e.g. ethical criteria) may lead to incompatible conventions which compete to gain the adherence of decision-makers.

Conventions evolve. By their nature of problem-solving, conventions are submitted to empirical tests - people may become disenchanted with an erstwhile strongly upheld convention if it does not solve the problems it intended to: witness the case of socialism in Eastern Europe. Alternatively, the criteria which structure the convention may loose legitimacy, as in the case of the divine right of monarchs.

Given those (possibly trite) comments on conventions in general, to be used later on, let us turn to "economic development of the less-developed countries". As it is well known, the deliberate pursuit of this objective became an issue after the Second World War, in the course of the Cold War. Since then "development" has been distinguished from "growth" by the occurrence of structural change. Development was not simply a matter of having "more of the same", it was about changing the composition of what we had. 
Simplifying the debate and keeping the focus on Brazilian history, we may say that the convention about development which held the hegemony from the end of the War to the mid-eighties considered that the structural change that mattered was the change of the productive structure industrialization, in short. The transformation of the productive structure would be achieved by institutional means: by the action of the State on the market.

This convention ascribed great importance to technical progress, putting the differences between center and periphery as regards the pace and appropriation of the results of technical progress at the heart of its justification of industrialization. Nonetheless, in its early stages this convention did not include in its positive agenda the development of a local innovation capability, relying on the imports of technology to bring about the desired technical progress, via direct foreign investment, technology licensing or embodied in capital goods. The positive agenda focused on the mastering of production capabilities.

However, in later stages, especially during the second half of the seventies, the innovation capability was included in the positive agenda, widening the concept of "local productive forces". This was especially significant in the "hightech" sectors, such as informatics, telecoms, aerospace and nuclear energy, where State intervention aimed not only at developing local innovation capability but also at establishing such capability in firms under national control.

During the early eighties the "productive structure" development convention begun to crumble as a consequence of the changes in the international credit market on which it had come to rely on. Such decay was compounded during the second half of the decade by its inability to deal with the issues of stability ${ }^{5}$ and the expectations arising from the end of the military regime. Such disrepute opened the gates for a new development convention.

At the time, the "neo-liberal convention" was already in full swing in the rest of the developing world, except for East Asia. The new convention rested not only on a well-developed critique of the failures of the preceding convention but also on a coherent set of principles and prescriptions which were capped by a teleological view of the world.

The theoretical underpinning of the reformers of the early nineties rested

5 In my view, the turning point was in 1987, after the failure of the Cruzado Plan. 
upon three pillars - the "rational expectations" neo-classical economics, the political science of public choice and coalitions theories and the historical approach of the "new institutional economics". All three converged to praise the market and berate the State. The assumption that national societies tended to converge towards the same pattern — market-driven liberal democracies provided a long-term perspective. Paving the way for such prospect, the Decalogue of the Washington Consensus (Structural Adjustment Programs in Africa) explained what should be done: open the economy in terms of trade, finance, direct investment and rights of property and reform the State by reducing regulation, privatization of State enterprises, fiscal equilibrium and efficient expenditures.

In our previous terms, the new convention provided a clear positive agenda to the decision-makers.

The new development convention turned the old convention upside down, in at least four fundamental aspects. First, policy-makers intended to transform what was seen as an "organic" (corporative) fabric of relationships into a more individualistic society - a truly liberal intention. ${ }^{6}$ Second, by defining structural reform in institutional terms only. If the institutional structure was duly reformed, development would follow. Third, by defining that the market was the institution that mattered. More specifically, the international market. Fourth, institutional uniformity across nations was a desired goal. Given sound and efficient institutions and natural comparative advantages the productive structure would follow suit and become efficient too.

As a consequence of this change, everything which was identified with the old development convention became part of the new negative agenda.

In the view of policy-makers, the institutional reforms would lead to two entwined virtuous circles, from which economic development would result. ${ }^{7}$ The first circle was related to the process of globalization, defined as the growth of trade and investment above the growth of production and the elimination of

\footnotetext{
6 The rhetorical expression of this was "to get rid of Vargas' heritage", Vargas being the President who ruled Brazil from 1930 to 1945 (mainly as a dictator) and from 1950 to 1954 (as an elected President). During his first tenure, a corporative structure was established, parts of which still exist (e.g. trade union organization and labor legislation) and heavy industry was started by a State-owned enterprise. Petrobras, the State oil monopoly was established during his second tenure. In the present context, he symbolizes the evils of the old pattern of development, especially State intervention in the market.

7 See Franco (1998) for a full version.
} 
distinctions between foreign and national capitals. Trade and foreign direct investment (FDI) would introduce competitive pressure into the erstwhile protected markets and bring in more modern machinery and inputs, increasing productivity. Trade and FDI are closely related: FDI requires freedom to import but, at the same time, has a greater propensity to export. In the long run such investment would lead to increases in productivity and hence to greater exports. It did not matter that a considerable part of FDI was directed to purchasing local (private and State-owned) firms, since this was a prelude to increases in productivity and greater exports. Therefore, the large deficit in the transactions account of the balance of payments was a temporary phenomenon as was the reliance on short-term international finance to fill in the foreign exchange gap. By the same token the very high interest rates required to attract financial capital would be short-lived.

The second virtuous circle was related to the internal market. Here, trade liberalization would lead to a progressive income distribution by acting as a brake on price increases by domestic producers and regional integration would enhance the domestic market further. Price stability would provide entrepreneurs with long term horizons. Privatization and de-regulation would coalesce with imports and FDI to increase competition. Wider markets, positive expectations and greater competition would lead to new investments and trade liberalization would allow the imports of new vintages of machinery and inputs and therefore to increases in productivity, exports and growth. Fiscal reform would support the decline of interest rates and more "flexible" labor legislation would reduce costs and increase international competitiveness. The adoption of an over-valued exchange rate strengthened the mechanisms of the two circles, linking further the stabilization and growth components of the strategy, but was not a necessary condition for their success.

Let us forget the failures of the market and suppose that the model had worked and high and sustained growth had been achieved in order to examine its consequences for scientific and technological activities (S\&TA) of enterprises, since the latter were, by definition, the main actor of the model. To do this it is useful to take a "portfolio" approach, whereby the firm is seen as a bundle of assets organized by routines and conventions which distributes its expenditures on new assets according to their expected costs, revenues and uncertainties over 
time. According to such view, technological assets are just one of the many assets in which a firm may invest. ${ }^{8}$ Moreover, technology assets are a portfolio in themselves, with different expected costs, revenues, uncertainties and timing. The structure of the latter portfolio defines the "technological strategy" of the firm.

The amount a firm' of investment in technological assets is conditioned by the technological opportunities and by the type of competition and user-producer relationships it faces in the sectors in which it operates, as well as by growth prospects, determined be macroeconomic conditions such as the rate of growth of the economy, the degree of international openness and income distribution. A crucial determinant of such investments is the national market for credit and capital, not only because it defines the availability of finance for technological assets but also because it defines the opportunity cost of technology investment (a feature normally overlooked in evolutionary analysis because it does not operate in the context of a "monetary economy" in the Keynesian sense). ${ }^{9}$ Obviously, the level of investment in technological assets is conditioned not only by macro and mesoeconomic factors: micro factors, such as the previous accumulation of technological assets by the firm and the routines and conventions attached to such history play an important role, as does the ownership and size of the firm and its financial capability to increase debt and/or run risks.

It is assumed here that, on the one hand, a firm has to maintain a minimal level of expenditures on technological assets to remain in business (e.g. for quality control and for minor product and process improvements). Such minimal level of expenditures is largely a consequence of the macro and mesoeconomic factors outlined above, such as the growth of the economy and the degree and type of competition prevailing in the market in which the firm operates. On the other hand, the increase in technological assets has limits too, given by a combination of meso and micro factors (e.g. the technological opportunities of the sector, the indebtedness capacity of the firm). In other words, firms invest in technology according to a floor and ceiling pattern.

Then, following the portfolio approach outlined above, what would have happened to the investment in technological assets had the reform development

\footnotetext{
8 The assets held by a firm include money (i.e. the "liquidity preference" in Keynesian parlance).

9 The approach outlined above (including the relationship between Schumpeterian and Keynesian "research programmes") is more fully developed in Erber (1999).
} 
strategy performed according to plan? A higher and sustainable rate of growth combined with an increase in competition stemming from trade and investment liberalization and de-regulation would probably lead to higher investments in technology, reinforced by longer time horizons, lower interest rates and lower wage costs. The floor of the investment level in ST\&A would probably be shifted upwards.

At the same time, trade liberalization would increase the competitive pressure on firms to use international process technologies and to supply products according to international standards. Globalization would also increase the time pressure to conform with international standards. Therefore imports of technology (embodied and disembodied) would become the most valuable asset in the technology portfolio. Although such imported assets require complementary local assets to be properly used (e.g. production engineering and detailed design skills) so as to adapt processes and products to local conditions, such local assets (many of which were already available in Brazil as a consequence of the previous period of industrialization) do not require a large deployment of resources and time to develop. Investment in non-incremental innovations locally developed, which would involve higher uncertainty and require longer time-horizons (i.e. lower time-discount rates) would be discouraged. Therefore the ceiling of the investment level would tend to be low.

Financial globalization, through the liberalization of the capital foreign exchange account imparted a further twist to the pattern outlined above. As mentioned, it was expected that finance capital would be needed to balance the expected current account deficit, filling in the gap left by FDI. In order to attract finance capital high internal interest rates would be necessary. However, high interest rates tend to shift the composition of the overall investment portfolio of firms towards financial assets, reducing the share of technological assets in the total portfolio. Moreover, high interest rates tend to shift the structure of the technology portfolio towards investments in assets with relatively short periods of maturity, such as local ST\&A directed to changes in management organization and adaptations of products and processes. In this context, firms having access to international sources of finance (i.e. with lower interest rates and longer maturity) were better placed to invest in local ST\&A. 
Given the macroeconomic strategy outlined above, the role of FDI in the definition of investments in technology is critical. First, international firms are supposed to set the pace at which the economy is growing and, therefore, the intensity of technological efforts. Second, more directly, by their size and connections international firms are better placed to carry out more ambitious technological programs (if they are likely to carry them out is an issue discussed below). Third, they exert an important influence on the ST\&A investments of their suppliers and customers, as well as of their local competitors. Fourth, FDI has transferred to foreign ownership some of the local firms which had developed significant technological assets, in the private sector (e.g. the leading auto parts producers) and privatized public companies (e.g. telecom). Finally, FDI dominates the sectors which are more technologyintensive within the productive structure of the country (especially in durable consumer goods and capital goods production).

It seems unlikely that firms which have easy access to technological assets already developed elsewhere (i.e. which are sunk costs from the point of view of the group as whole) will replicate such investment under conditions where there are less economies of scale and scope and less externalities deriving from a long-established national system of innovation. Under such circumstances, R\&D facilities set up by the companies FDI purchased could easily become redundant.

It is nothing but rational behavior for subsidiaries of transnational companies to concentrate technology investments mainly on adaptations of products and processes developed elsewhere to specific local conditions, such as raw materials or income distribution. Such new products and processes will probably require innovations in production engineering in the plants of the TNCs subsidiaries and, via linkages of production and use, in their suppliers and customers. As a consequence the floor of S\&T expenditures would be raised, but the effect on their ceiling would be very limited - the local chains of production dominated by TNCs subsidiaries would become efficient producers, efficient users of innovations developed elsewhere.

The establishment and operation of the two virtuous circles was fully entrusted to market mechanisms enhanced by State reform. If the latter had conformed to the intentions, fiscal constraints would be reduced and 
expenditures could be increased eventually. Here, however, the positive and negative agendas interacted strongly.

In the past, there was an apparently straightforward answer: the State should intervene where there were market failures in order to restore Pareto-efficiency. A complication arose when several market failures co-existed. If it is impossible to remove all failures simultaneously, welfare economics says that there is no a priori Paretian criterion to select which imperfection to remove first and no guarantee that an imperfect situation is better than another (Nath, 1969). Under such circumstances external criteria, deriving from other economic and political sources, must be used to select priorities, as Lall (1994) argues was done in Southeast Asia. Dealing with market failures through State intervention was further complicated by the introduction of State failures, in the aftermath of the neo-liberal revolution. In fact, for the reformers of the nineties, the problems caused by State intervention tended to outweigh the negative results of market failures and State intervention was placed at the top of their negative agenda. Given the analytical problems involved in comparing two imperfect situations, this was an a priori judgment, based on anti-State and pro-market biases. Possibly for such reasons decision-makers in Brazil remained divided about the relevance of market failures for State action.

The discussion of market and State failures was very important for the development of innovation capabilities, since it is generally recognized that the market fails considerably in areas such as human resources development, basic research and development projects which have more uncertain, long-term results, especially in contexts where the credit and capital markets are very incomplete and operate poorly.

Since the development convention offered mixed answers and opinions of the decision-makers diverged, a compromise solution was found: the existing State mechanisms for human resources development were maintained, but Federal funding of S\&T did not increase and university research was geared as much as possible to the needs of enterprises. More recently, when the neoliberal development convention was already showing strong signs of failure, the Ministry of Science and Technology was able to garner para-fiscal resources to increase its budget.

Human resources and educational and scientific institutions are necessary 
but not sufficient conditions for innovation. Enterprises provide the necessary complement, especially in a world where comparative advantages are constructed and managed by the cooperation between Government and private enterprises and where international trade grows faster in the more technology-intensive products. In other words: if $S \& T$ is to be efficacious to promote development, it must be integrated to industrial policy.

To the symbolic question "is there an intrinsic difference between potato chips and computer chips?" the neo-liberal convention answered categorically "no!". If a country had given comparative advantages in potato chips, it should stick to them. Sector policies were the emblem of the abhorred past and occupied the highest rank in the negative agenda. Industrial policies with a strong local technological content having the objective of achieving greater autonomy of decisions were the worst of all.

The negative reply to the chips question implies that the issue of the productive structure is irrelevant. Therefore it misses a crucial aspect of development: sectors play different roles in the process of generation and diffusion of innovations. Since the First Industrial Revolution, a few sectors, science-based, have acted as engines of innovations, which are then absorbed by sectors which supply production goods to the rest of the economic system. The strength of the sectors which act as engines and transmitters of innovations within a productive structure go a long way to explain the dynamics of such structure by virtue of the creation and diffusion of innovations, economies of proximity, scope economies, transaction costs and international competitiveness. In short, the negative answer is wrong.

But chassez le naturel et il revient au galop: as shown in Table 2, the production and exports of manufactures in Brazil are concentrated on products of low and medium intensity of technology while imports are concentrated on products of high and medium intensity. As a consequence, imports tend to have a higher income elasticity than exports and trade deficits are a structural feature, raising Prebisch's specter from his grave. In fact, high-tech products such as electronics, chemicals and the more complex capital goods account for the bulk of Brazil's trade deficit. Exports of highly technology-intensive products consist mainly of products of the airplane industry, established, ironically, under the deprecated ancien régime. 
Structure of Brazilian Industrial Production ( $Y$ ); Exports $(X)$ and Imports $(M)$ According to Technology Level of Products as a Percentage of Total Value - 1998

\begin{tabular}{lccc}
\hline Technology Level & \multicolumn{3}{c}{ Value (\%) } \\
& Y & X & M \\
Low & 58 & 54 & 26 \\
Medium & 31 & 35 & 50 \\
High & 11 & 11 & 24 \\
Total & 100 & 100 & 100 \\
\hline
\end{tabular}

Source: Moreira (1999). [my estimates]

The observation of the structural difference between imports and exports and of its implications for the foreign exchange constraint is not new. It goes back to the eighties, when the late Fernando Fajnzylber from ECLAC warned us about it. It is true that for a neo-liberal, ECLAC could be seen as a suspect source, but the warning was repeated in the early nineties by economists above suspicion, which became members of the Government, such as Baptista and Fritsch (1993). Nonetheless, the economic policy remained deaf to the need to change the productive structure - a testimony to the force of the negative agenda.

The policies eventually directed to specific sectors had essentially a defensive nature, designed to compete with Argentina for foreign investment (e.g. automobiles) or to fight unfair foreign competition (e.g. shoes). Coherently with the neglect of the structural dimension, they did not encompass any view of the desired sector structure nor any specific incentives to foster local innovation. The Government put some incentives (mainly credit and fiscal) on its window-shop and enterprises came to get them, driven by the market. A far distance from the policies followed in China and in Southeast Asia.

The chapter on the "evils of picking the winners" of the negative agenda probably played another role: preventing negotiations with TNCs. Nothing was asked of such companies in exchange for the incentives they received 
(e.g. setting up facilities for technological development, fostering local suppliers, etc.). As shown by the recent Chinese experience, the greatest recipient of FDI, such negotiations are part of the market and can be profitably used by the recipient country to develop its technical resources.

To sum it up: the neo-liberal development convention through its two agendas, positive and negative, implied a modernization of the existing productive capacity, at the level of enterprises and of the economic structure, but it did not lead to an increase in the innovation capability of the economy, either at the micro level or at the level of the economy as a whole. Such results are consistent with the facts pointed out in the preceding section.

\section{Conclusions}

The record of neo-liberal convention is mixed. It did produce a great institutional change, increasing the role markets play in social and economic life and reducing the roles of the State. More specifically, it helped to consolidate a convention of stability, building upon the rejection of inflation which spread during the last stages of decay of the "developmental State". Those are not mean achievements.

Nonetheless, its development record is poor. As a consequence of its two agendas, positive and negative, the virtuous circles became vicious circles. The positive agenda rested on macro and micro assumptions which were dubious at the time they were made and which were falsified empirically. This is the case of assumption that the financial market would continue to provide funds to "emerging markets", which was maintained even after the Mexican and Asian crises had shown otherwise. It is also the case of the assumption that FDI would lead to great exports, notwithstanding the fact that a great part of such investment was directed to non-tradables and, in the case of tradables, to the internal market. ${ }^{10}$ The negative agenda prevented the inclusion of the change of the productive structure as an issue to be tackled.

The viciousness of the circles is shown by low and unstable rates of growth, very high rates of unemployment, rise of urban violence and by the present

10 The internal market was eventually broadened to include the Mercosul. See Laplane and Sarti (1998). 
macro-economic trap. The latter has welded the foreign exchange and fiscal constraints via a monetary policy which maintains the highest interest rates of the world in order to attract an increasingly reticent foreign finance capital so as to close the current transactions deficit. It does so at the cost of increasing exponentially the public debt, which is increasingly foreign exchange-indexed.

As a result of such dismal record, the neo-liberal convention has lost its hold and now is challenged openly by the four candidates in the coming Presidential election. Although a new convention has not yet emerged, there is at least a consensus: all candidates agree on one point, the need to expand exports and to limit imports in order to reduce the current account deficit and thus the reliance on foreign finance, dismantling the vicious circle above described. Industrial policy is now part of the positive agenda again. But will it be a policy which emphasizes innovation?

I have argued in the two previous sections that the type of technological capability found in Brazilian industry is consistent with the results expected from the good working of the neo-liberal convention. The failure of the convention strengthened the features of the expected technological capabilities, augmenting the bias in favor of financial investment in the general portfolio of the firms and the bias in favor of projects with low uncertainty, short maturation period and few sunken costs within the technology portfolio. Innovation projects tended to fare worse in the actual working of the neoliberal convention than in its theory.

Given the high elasticity of imports, a trade surplus can always be obtained by keeping growth rates curbed, as in the present. However, since resuming growth is one of the main objectives of all candidates, achieving a trade surplus can be obtained only by expanding exports substantially and by substituting local production for imports.

My conjecture, based on the arguments of the preceding section, is that such double movement can be achieved only if the composition of tradable goods is shifted towards more technology-intensive products. This implies two complementary strategies: increasing the technology content of the chains of production already existent and changing the structure of industry by the inclusion of the sectors which are the engines and transmitters of innovation, especially electronics and capital goods. Such strategies would lead to a substantial 
increase in the innovation capability of the Brazilian economy, making such capability an integral part of the positive agenda of the new development convention.

\section{References}

Batista, J.; Fritsch, W., "Dinâmica Recente das Exportaçôes Brasileiras (1979-90)”, in Velloso. J.; Fritsch, W. (orgs.), A Nova Inserção Internacional do Brasil, Rio de Janeiro: José Olympio Editora, 1993.

Carvalho, P., "As Causas do Aumento da Produtividade da Indústria Brasileira nos anos 90", PhD thesis, Rio de Janeiro: IE/UFRJ, 2000.

Castro, A., "Renegade Development: Rise and Demise of State-Led Development in Brazil", in Smith, W.; Acuña, C.; Gamarra, E. (eds.), Democracy, Markets and Structural Reform in Latin America, Transactions Publishers, 1993.

; Proença, A., “Novas Estratégias Industriais: Sobrevida ou Inflexão?”, mimeo, Rio de Janeiro: Fórum Nacional, 2001.

Erber, F., "Science and Technology Policy in Brazil: a Review of the Literature", in Latin American Research Review, v.16, n.1, 1981.

; Amaral, L., "Os Centros de Pesquisa das Empresas Estatais: um Estudo de Três Casos", in Schwartzman, S. (org.), Política Industrial, Mercado de Trabalho e Instituições de Apoio, Rio de Janeiro: Fundação Getúlio Vargas, 1995.

"O Sistema de Inovações em uma Economia Monetária: uma Agenda de Pesquisas", in Cassiolato, J. E.; Lastres, H. (orgs.), Globalização \& Inovação Localizada - Experiências de Sistemas Locais no Mercosul, Brasília: IBICT/MCT, 1999.

Franco, G., "Inserção Externa e Desenvolvimento", in Revista de Economia Política, v.18, n.3, 1998.

Lall, S., "The East Asian Miracle: does the bell toll for industrial strategy?", in World Development, v.22, n.4, 1994.

Lakatos, I., "Falsification and Methodology of Scientific Research Programmes", in Lakatos, I.; Musgrave, A. (eds.), Criticism and the Growth of Knowledge, London: CUP, 1970. 
Laplane, M.; Sarti, F., "Novo Ciclo de Investimentos e Especialização Produtiva", in Reis Velloso, J.P. (org.), O Brasil e o Mundo no Limiar do Novo Século, Rio de Janeiro: José Olympio Editora, 1998.

MCT — Ministério da Ciência e Tecnologia (2001) — Ciência, Tecnologia e Inovação: Desafio para a Sociedade Brasileira, Brasília: Livro Verde.

Moreira, M., "A Indústria Brasileira nos Anos 90: o Que Já se Pode Dizer?", in Giambiagi, F.; Moreira, M. (orgs.), A Economia Brasileira nos Anos 90, Rio de Janeiro: BNDES, 1999a.

Nath, S., A Reappraisal of Welfare Economics, London: Routledge and Kegan Paul, 1969.

Quadros, R.; Furtado, A.; Bernardes, R.; Franco, E., "Technological Innovation in Brazilian Industry: an Assessment Based on the São Paulo Innovation Survey", Austin: International Conference on Technology Policy and Innovation, mimeo, 1999.

Schön, D., "Generative metaphor: A Perspective on Problem-Setting in Social Policy", in Ortony, A. (ed.), Metaphor and Thought, Cambridge University Press, 1993.

SOBEET - Sociedade Brasileira para o Estudo de Empresas Transnacionais - "Comportamento Tecnológico das Empresas Transnacionais em Operação no Brasil”, in Conjuntura Econômica, março, 2000.

Sabóia, J.; Carvalho, P., "Produtividade na Indústria Brasileira: Questōes Metodológicas e Análise Empírica", in Texto para Discussão 504, Rio de Janeiro: IPEA, 1997. 